\title{
DISPUTANDO A MORAL PÚBLICA: A AÇÃO CATÓLICA DURANTE O PRIMEIRO GOVERNO PERÓN (TUCUMÁN-ARGENTINA, 1946-1955)
}

Disputing public moral: the Catholic Action during Perón's first term (Tucumán-Argentina, 1946-1955)

LUCIA SANTOS LEPERA

http://dx.doi.org/10.1590/S0103-21862015000100007

Lucia Santos Lepera é doutora em História pela Universidad Nacional de Tucumán, na Argentina, e bolsista de pós-doutorado do CONICET (Consejo Nacional de Investigaciones Científicas y Técnicas) (luciasantoslepera@gmail.com).

Artigo recebido em 10 de dezembro de 2014 e aprovado para publicação em 7 de abril de 2015.

Tradução de Dora Rocha. 


\section{Resumo}

0 artigo se propõe analisar o modo como a Ação Católica de Tucumán (ACT) disputou a moral pública no quadro da chegada do peronismo ao poder em 1946. Sustenta que, a partir do imperativo de moralização social, os setores católicos exerceram influência sobre as agências estatais e desafiaram a autoridade policial. No final dos anos peronistas, operaram-se sensiveis transformações nos sentidos da moralização que o laicato estava procurando transmitir, bem como nos modos da sua ação. Avança-se assim para o estudo das mudanças que converteram o discurso moral católico em um desafio político contra o governo.

Palavras-CHave: Ação Católica; moral pública; peronismo; Tucumán.

\section{AbSTRACT}

The article intends to analyze the way Tucumán's Catholic Action (ACT) has disputed the public moral when Perón began his first term in Argentina government in 1946. It sustains that, facing the imperative of social morality, the catholic sectors influenced state agencies and defied police authority. Towards the end of peronists years, sensitive transformations were operated in the senses of moralization that the laity was trying to impart as well as in the ways of doing it. Finally the text points the changes that converted the catholic moral discourse in a political challenge against the government.

KeYwords: Catholic Action, public moral, peronismo, Tucumán.

\section{RÉSUMÉ}

L'article se propose d'analyser la manière dont l'Action Catholique Tucumana (ACT) a disputé la moralité publique dans le cadre de l'arrivée au pouvoir du péronisme en 1946. II affirme que, à partir de l'impératif de moralisation sociale, les secteurs catholiques ont exercé influence sur les agences de l'État et ont défié l'autorité policière. Vers la fin des années peronistes, des sensibles transformations se sont opérées dans les sens de la moralisation que le laïcat cherchait à dispenser ainsi que dans les modes de le faire. Le texte se tourne ensuite à l'étude des changements qui ont fait du discours moral catholique une contestation politique du gouvernement.

Mots-CLÉs: Action catholique, morale publique, peronismo, Tucumán. 


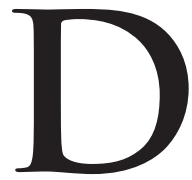

urante o primeiro governo Perón (1946-1955) inaugurou-se uma fase de profundas transformações políticas, econômicas e sociais cujos desdobramentos marcaram a história contemporânea argentina. 0 movimento político liderado por Juan Domingo Perón erigiu-se no símbolo da classe operária e de vastos setores populares, atores que, a partir da conquista de direitos sociais, vivenciaram nesse processo uma "revanche" diante da marginalização experimentada em governos anteriores (James, 1999: 19-65). Assim, a alteração das hierarquias sociais, que implicou por sua vez a perturbação de uma ordem moral, se converteu num dos traços constitutivos do processo político iniciado em 1946.

O peronismo implicou uma "agitação" da moralidade popular, à qual ele imprimiu uma nova relevância (Acha, 2013: 33). Como foi assinalado em pesquisas anteriores sobre essa etapa (Adamovsky, 2009), os traços "plebeus" do peronismo e a atitude desafiadora de seus seguidores diante das normas de respeitabilidade e decência puseram em questão os critérios culturais, sociais e morais até então predominantes. Essa espécie de revanche da cultura plebeia impactou a sociabilidade urbana, provocando a reação de setores do laicato católico contrários aos ditos processos de transformações. Este artigo trata dos modos como a Ação Católica - principal associação laica da Igreja - procurou disputar a moral pública, considerando seus vínculos flutuantes com o governo peronista.

A trajetória da Ação Católica Argentina (ACA) durante o primeiro governo Perón chamou a atenção da historiografia em virtude do papel de destaque que os quadros da associação assumiram no golpe de Estado de 1955. Sua abordagem fez parte de pesquisas mais amplas sobre a relação da Igreja católica com o governo, as quais buscaram decifrar a virada de uma vinculação estreita para um enfrentamento aberto entre as duas instituições (Caimari, 1995; Bianchi, 2001; Di Stefano y Zanatta, 2000: 435-460). Desse modo, a análise do laicato católico durante os últimos anos peronistas tornou-se fundamental para dar conta do processo que pôs fim ao governo de Perón e que teve a Igreja como um ator central.

Em grandes linhas, a história da ACA foi representada como tendo tido um período ascendente e entusiasta que abarcou os anos 1930 (desde sua fundação em 1931), ${ }^{1}$ seguido de uma fase de crise e ruptura no início dos anos 1940, e de um novo passo no sentido de reconquistar espaços sociais nos alvores da década de 1950 (Acha, 2010: 7-42). Os estudos coincidiram em assinalar uma reativação da militância laica por volta de 1952, impulso que 
buscava promover o ativismo militante de anos anteriores e que se articulou em torno de dois eixos. De um lado, a organização da classe média a partir da criação do grupo de Profissionais e Estudantes Católicos (APAC), iniciativa que adquiriu um tom desafiador frente ao governo peronista, replicando o perfil crescentemente oposicionista que assumiram esses setores. De outro lado, esse renascimento se nutriu das crescentes impugnações morais ao governo, tópico de forte influência nas fileiras católicas e que ativou a mobilização de militantes da ACA (Caimari, 1995; Acha, 2007; Adamovsky, 2009). Esse processo, analisado principalmente na cidade de Buenos Aires e na província de Córdoba (Tcach, 1991), outorgou à ACA grande visibilidade pública e uma inesperada capacidade de mobilização, convertendo-a num ator capaz de concitar amplas adesões políticas e sociais com o fim de exercer oposição ao peronismo. ${ }^{2}$

Em virtude dessas considerações, este artigo se propõe analisar a Ação Católica de Tucumán (ACT) e a reação moral que caracterizou suas fileiras no marco da chegada do peronismo ao poder em 1946. Ele sustenta que, durante os primeiros anos de governo, a associação católica buscou se articular com o Estado com o objetivo de disputar a moral pública. Nesse contexto, a direção da ACT estabeleceu uma vinculação com as agências estatais, em especial com a polícia da província de Tucumán e com a Comissão de Moralidade da Prefeitura da capital da província, San Miguel de Tucumán. Não obstante, se a moral pública foi uma das premissas através das quais os setores católicos exerceram influência nas agências estatais, ela também se converteu num problema que se colocou, pouco a pouco, como um dos limites mais claros do apoio ao governo. Desse modo, o trabalho avança na análise dos signos que revelaram as mudanças nos sentidos da moralização que buscava impor o laicato, assim como nos modos de projetá-la.

Em segundo lugar, a investigação se pergunta se a "ofensiva" católica que se cristalizou por volta da década de 1950 teve dinâmicas similares às analisadas na província de Córdoba e na capital do país. Sustenta-se que, para além do ímpeto que impregnou o discurso moral católico, este não teve seu correlato numa "ofensiva" da associação contra o governo peronista. Esta afirmação permite repensar as mudanças por que passou a Ação Católica e as respostas que a associação ensaiou diante das tentativas nacionais de reativar o movimento e imprimir um tom mais ofensivo à sua militância.

\section{A bUSCA DE ARTICULAÇÃO COM AS AGÊNCIAS ESTATAIS}

D esde sua fundação em 1932 o objetivo da ACT consistiu na catolicização de todos os âmbitos da sociedade. Esse objetivo condensou diferentes formulações, entre as quais se destacou a custódia da moral pública. ${ }^{3}$ Nesse sentido, a catolicização foi entendida do pon- 
to de vista de uma moralização baseada na difusão de um comportamento ético atravessado por una forte marca de classe. Os dirigentes da associação, representantes dos setores urbanos da classe média e (principalmente) alta, buscaram erigir-se em guardiães dos costumes da sociedade provincial, objetivo que os levou a exercer pressão para impor a moral católica no tocante à moda feminina, aos espetáculos públicos e aos conteúdos de revistas e periódicos.

Tais imperativos morais adquiriram novas enunciações no contexto da irrupção do peronismo no cenário de Tucumán. Esse processo revelou com eloquência as arestas disruptivas que 0 novo movimento político comportou ao impulsionar a organização dos trabalhadores da indústria do açúcar na FOTIA (Federação Operária de Trabalhadores da Indústria Açucareira), sindicato que se converteu num pilar de sustentação chave do peronismo em Tucumán e erigiu a província num dos bastiões desse movimento no interior do país (Rubinstein, 2006). ${ }^{4}$ Desse modo, ao conquistar novos espaços de poder (conquista expressa na ocupação de cargos legislativos, na adjudicação do controle do Partido Peronista e nas numerosas paralisações que realizaram para tornar efetivas suas reivindicações trabalhistas), os setores operários adquiriram uma centralidade e um protagonismo sem precedentes na história provincial. Esse avanço de setores largamente marginalizados dos espaços políticos e sociais também se refletiu em questões menos tangíveis como foi a dignidade e a autoestima dos trabalhadores, e a reivindicação da moral popular.

A maior circulação da música popular nos espaços de recreação e sociabilidade urbana, o espírito festivo dos atos peronistas, a ocupação irreverente das ruas centrais por aqueles que haviam permanecido apartados desse mundo reservado aos notáveis, constituíram aspectos disruptivos que se converteram em gestos políticos. Tal como foi analisado por Ezequiel Adamovsky, foram mostras de uma espécie de "revanche da cultura plebeia" (2009: 265276). Como veremos, a reação moral que caracterizou as fileiras do laicato se desenvolveu no marco desse conjunto de mudanças potencializadas pela chegada do peronismo ao poder em 1946. A ação moralizadora da ACT converteu a associação num ator, mais do que disputou a moral pública, e com esse fim buscou se articular ao Estado.

A ACT divulgou suas ações moralizadoras a partir de um órgão especializado: o Secretariado de Moralidade. Seus integrantes foram apontados como os responsáveis pelo estudo e solução dos problemas vinculados à dignificação e recristianização da família e daqueles relativos à defesa da moralidade pública, baseada numa noção de decência e decoro social. A chave para projetar tais imperativos foi a vinculação traçada com as agências estatais, em especial com a polícia da província e a Comissão de Moralidade da Prefeitura da Capital. O Secretariado de Moralidade atuou em estreita colaboração com essa entidade, através da qual canalizou muitos de seus projetos. A ACT interpelou o Estado conseguindo, desse modo, alguns resultados favoráveis que impregnaram suas fileiras de otimismo e ativaram sua militância. 
A partir das gestões realizadas pelo bispo de Tucumán Agustín Barrere, e pelos membros da Junta Diocesana (JD) da ACT, o diretor do Secretariado de Moralidade da ACT foi aceito como membro integrante da Comissão de Moralidade da Prefeitura da Capital. 0 principal objetivo seria "facilitar a classificação de filmes" que integravam os programas dos cinemas: dessa forma, a direção laica poderia influir para que tal classificação respeitasse o ponto de vista da moral católica. ${ }^{5}$ Por outro lado, a ação conjunta com a Comissão oficial de Moralidade levou a ACT a concretizar uma de suas demandas mais ruidosas: a censura dos espetáculos públicos do Parque 9 de Julho.

O Parque, principal espaço verde da cidade de San Miguel de Tucumán, representava no imaginário dos militantes católicos o espaço urbano de maior corrupção moral, onde se reuniam prostitutas, se escondiam "delinquentes", os casais jovens fugiam do olhar dos pais, e onde se gerava todo tipo de atividade "imoral". Se em anos anteriores esse tipo de preocupação afetava na realidade as zonas periféricas da cidade e os bairros suburbanos, desde meados da década de 1940 esses "males" pareciam ter invadido o próprio coração da capital, o que despertou maior consternação entre o laicato.

Em consequência da pressão exercida pela direção da ACT, em 1947 o intendente da capital, por meio de um decreto, facultou aos integrantes da Comissão de Moralidade atuar nessa jurisdição. Ou seja, a nova disposição outorgou à comissão poder para desempenhar funções de "controle" e "denúncia" dos espetáculos e reuniões públicas que não se ajustassem a "normas de moral e bons costumes" (La Gaceta, Tucumán, 7 de fevereiro de 1947, p. 7). Isso significava que a comissão ficava autorizada a solicitar a intervenção do "Poder Executivo em caso de necessidade de sanções". A implementação da nova medida teve arestas muito particulares dado que, na prática, as denúncias dos eventos que brigavam com a moral foram feitas pela ACT. A associação católica exerceu a função de polícia através de um "corpo de ação" formado por um núcleo de jovens que faziam circular as denúncias até a Comissão oficial de Moralidade, solicitando as sanções e censuras pertinentes. Esse singular "corpo de ação" católico, cujo funcionamento dependia do Secretariado de Moralidade da ACT, foi constituído não só para controlar a moral pública na jurisdição do Parque 9 de Julho, mas também estava encarregado de comunicar toda entrada de menores nos cinemas, denunciar "vitrines imorais", avisos em bondes e ônibus etc. ${ }^{6}$

Desse modo, a ACT não só disputava a moral pública, mas desafiava a instituição que tradicionalmente havia concentrado o poder de controle sobre a ordem social: a polícia. 0 tão ambicionado papel de guardiães da moral pública parecia viável a partir da articulação com as agências estatais, onde seus membros encontraram, ainda que parcialmente, receptividade às suas principais demandas. Convencidos desse papel, os militantes católicos não só recor- 
reram em várias oportunidades à Comissão de Moralidade oficial, como também apelaram diretamente às autoridades policiais, municipais e provinciais buscando sua intervenção com o objetivo de proibir peças de teatro, sessões de cinema, desfiles de moda, bailes etc. ${ }^{7}$ Por exemplo, com base na premissa da "defesa da moral", a ACT recorreu à polícia da província para propor a suspensão de bailes de natal e solicitar a regulamentação dos festejos de carnaval, pedido que foi "bem recebido". 8

A partir da defesa de um sentido da moral - vinculado ao ideal de decência, de hierarquia familiar e decoro social -, a associação católica reagia diante de um tipo de sociabilidade que adquiriu maior visibilidade com o peronismo. Não foi uma resposta isolada, mas sim algo que integrou o que Adamovsky chamou de uma "reação hierarquizadora" que caracterizou os setores médios e altos urbanos, cujo mal estar, em grande medida, se vinculava à "debilitação das normas culturais e das hierarquias e preeminências sociais habituais" (2009: 276).

Por seu lado, o governo peronista expôs suas ambivalências frente às demandas católicas de moralidade. Se, por um lado, se mostrou permeável e cedeu espaços frente a tais demandas, por outro lado impulsionou expressões e condutas sociais que se opunham ao imperativo católico de "moralização". Vejamos, por exemplo, o modo como se promoveram concepções em torno do esporte e da saúde que entraram em tensão com a moral católica que os quadros laicos buscavam impor. As tensões implícitas nessa relação afloraram em torno das atividades fomentadas pelo Departamento de Educação Física da Universidade Nacional de Tucumán (UNT), criado em 1946 de acordo com os parâmetros de difusão do esporte que o governo peronista impulsionou. Num primeiro momento, o bispo diocesano Agustín Barrere reconheceu sua fundação com elogios às autoridades universitárias que inauguravam "um centro de educação integral nas atividades desportivas" (Trópico, Tucumán, 30 de Janeiro de 1947, p. 5). Sem dúvida, em pouco tempo as atividades promovidas pelo Departamento acarretaram críticas dos católicos militantes, que denunciaram a instalação de uma piscina para natação de caráter misto e solicitaram - junto às autoridades universitárias e provinciais - a suspensão dos desfiles de banhistas cuja "indumentária imoral" resultava alarmante. ${ }^{9}$

Nesse sentido, a moral delineada pela ACT postulava "valores" católicos tributários de um ideário que, não sem certas doses de falsidade, reproduzia as preocupações das classes médias e altas urbanas. Nessa perspectiva, o laicato católico reivindicou o "dever" de intervir em "defesa da moral", fundamento que o levou a interpelar os poderes públicos e, em caso de não obter resultados satisfatórios, a não hesitar em lamentar a possibilidade de valer-se de "seus próprios meios". 10

Com efeito, a ACT havia dado uma mostra do que implicava mobilizar seus quadros e valer-se "de seus próprios meios" quando enfrentou no final de 1948 o projeto de lei de 
"Profilaxia Social", que incluía a legalização dos prostíbulos por razões de higiene. Nessa oportunidade, a ACT organizou uma campanha maciça de repúdio, conjuntura em que logrou articular seus distintos ramos em torno de uma questão moral inquietante para a Igreja. Os setores católicos levantaram a voz pedindo o cumprimento sem modificações da lei 12.331 (que fora sancionada em 1936 e proibia o estabelecimento de casas para o exercício da prostituição), opondo-se ferrenhamente à inclusão do que consideravam a "legalização do comércio sexual" (Caimari, 1995: 123). Embora a campanha tenha sido organizada em nível nacional (as diretivas partiram da Junta Central) a associação pôde então constatar o êxito de sua iniciativa na província em defesa da moral e da "dignidade da mulher".

A moral católica disputava a cena pública num marco em que, simultaneamente, se estimularam outros sentidos de moralização, muito distintos das ideias de decência, respeitabilidade e decoro promovidas pela Igreja. Essas disputas se enunciaram com maior ênfase por volta dos anos finais do peronismo, quando se cristalizou um conflito de moralidades que envolveu, entre oturos, a ACT. Em suma, se a moral pública foi uma das premissas através das quais os setores católicos buscaram se articular com o Estado, ela também se converteu num problema que se colocou, pouco a pouco, como um dos limites mais claros do apoio ao governo. Como veremos, a partir de 1953 tal problema se converteu numa das principais causas de impugnação do peronismo.

\section{O laicato Católico E os SEnTIDos da "MORALIZAÇÃo"}

partir de 1952 sucederam-se importantes mudanças que afetaram tanto a instituição
eclesiástica como o governo provincial. No princípio desse ano faleceu o bispo Agustín Barrere, substituído por Juan Carlos Aramburu, que já exercia funções na diocese como auxiliar desde 1947. 0 estilo de condução do novo prelado apresentou profundas diferenças do de seu antecessor, caracterizado - como veremos - por uma atitude idependente frente às mudanças que atravessaram o movimento laico e a dinâmica política provincial, aspectos que ajudaram a diluir a figura do novo bispo no funcionamento da instituição eclesiástica (Santos Lepera, 2012). Assim mesmo, nesse ano renovaram-se as autoridades do governo provincial. Além de vencer de modo esmagador as eleições, que confirmaram a ampla adesão peronista da população de Tucumán, o 4 de junho confirmou em seu cargo o governador Luis Cruz.

Luis Cruz, trabalhador ferroviário, assumiu o governo da província como representante dessa vertente sindical. 0 caráter obreirista da sua candidatura foi um tópico destacado em seus discursos de campanha e posteriormente ressaltado em seus discursos como governador. Desde o primeiro momento, a fórmula da raiz operária sacudiu sensibilidades de classe 
gerando descontentamento entre os setores médios e altos da Capital. Para esses setores, a figura de Cruz expressou uma prova do caráter desafiante do peronismo ao pôr em questão os critérios de "respeitabilidade" próprios da classe política que se haviam arraigado em setores da sociedade argentina desde as primeiras décadas do século XX (Adamovsky, 2009: 276). 0 governo de Cruz potencializou o desprezo contra as classes baixas que a irrupção do peronismo havia despertado entre os setores acomodados e que se expressaria sem disfarces nos estertores da experiência de seu governo, no calor do aprofundamento da antinomia peronismo-antiperonismo. Assim o revelou a reação que provocaram os acontecimentos desencadeados no final de 1953, os quais marcaram um ponto de inflexão ao se converterem num catalisador das animosidades de classe, logrando unir o laicato católico e setores políticos opositores em suas críticas dirigidas ao governo local.

Nos primeiros dias do mês de agosto de 1953 a sociedade de Tucumán ficou abalada quando o principal diário da província publicou a impactante notícia de uma série de agressões e vexames sofridos por crianças da capital nas mãos de "indivíduos amorais" (La Gaceta, Tucumán, 6 de agosto de 1953, p. 4). Ainda que não tenham explicitado quem tinham sido os responsáveis pelo episódio de agressão, as notas do jornal não deixaram de assinalar o medo generalizado nos lares de Tucumán com crianças em idade escolar, cujas mães foram advertidas dos perigos que estas corriam se não fossem resguardadas dos "depravados", e insistiram na degradação moral que inquietava a população (La Gaceta, Tucumán, 14 de agosto de 1953, p. 5). Desse modo, o desprestígio da força policial, que já havia sido denunciada nos meses anteriores pelo encobrimento de um assassinato e por sua inação frente ao aumento de delitos na capital, eclodiu quando diferentes setores uniram suas críticas contra a negligência diante de um ato tão sensível à sociedade. ${ }^{11}$ Dadas as objeções crescentes, o chefe de polícia assumiu os problemas que flagelavam a população ligados aos "atentados cometidos por indivíduos amorais em detrimento de crianças de pouca idade" e se comprometeu a dar as respostas que fossem necessárias (La Gaceta, Tucumán, 14 de dezembro de 1953, p.4). Em suma, os acontecimentos de agosto geraram uma grande agitação e dispararam as críticas dos setores oposicionistas que, às denúncias de corrupção política e econômica dirigidas ao governo de Luis Cruz, somaram agora a impugnação ligada à corrupção moral.

0 episódio assinalado serviu como disparador para que o principal partido de oposição, a União Cívica Radical (UCR), utilizasse o problema moral como uma impugnação política contra o governo peronista local. Com efeito, o bloco de deputados desse partido solicitou ao ministro de governo que informasse à legislatura as causas da "negligência manifesta" e da "despreocupação" do Departamento Geral de Polícia em reprimir os "inúmeros casos de atentados ao pudor" e os "atos aberrantes" que se observavam em Tucumán (La Gaceta, 
Tucumán, 2 de outubro de 1953, p. 3). Os radicais dirigiram as acusações diretamente contra o governo e, em especial, contra a polícia enquanto principal responsável pela ordem pública. Desde a contundente derrota de 1946, a UCR havia formulado recorrentes apelos aos setores católicos, os quais haviam naufragado frente às inúmeras manifestações de colaboração sustentadas entre a instituição eclesiástica e o peronismo. Não obstante, na nova conjuntura 0 radicalismo intensificou os gestos que procuravam mostrá-lo como um partido permeável aos postulados do catolicismo, reeditando as tentativas de aproximar-se de setores que antes se mostravam hostis (Santos Lepera y Lichtmajer, 2013: 123-143).

Diante das reclamações dos radicais em decorrência dos acontecimentos de agosto de 1953, os dirigentes da Ação Católica somaram imediatamente sua voz, mas procurando capitalizar o conflito para impor seu próprio sentido de moralização. Preocupados com os "últimos acontecimentos ocorridos na província de domínio público", solicitaram audiências com 0 governador e o intendente municipal com o objetivo de insistir na necessidade de reprimir com maior ímpeto as publicações e os espetáculos públicos "impudicos", nos quais identificaram a raiz dos problemas que a população atravessava. ${ }^{12}$

Por seu lado, as autoridades policiais, diante da incômoda situação em que foram colocadas pelas crescentes objeções morais proferidas pela oposição política e os setores católicos, decidiram organizar um ciclo de palestras sobre a "função social" da entidade. Nelas se fez um chamado à colaboração da sociedade para reprimir os "feitos amorais" que se vinham observando, reconhecimento tácito da divulgação que as críticas haviam cobrado. Mas elas também puseram em evidência um sentido de "moral pública" muito distinto do exposto pelos setores oposicionistas e pela ACT, vinculado neste caso a uma ideia da ordem social cuja principal ameaça não residia na imoralidade de espetáculos ou na circulação de revistas impudicas, e sim nas contravenções que tradicionalmente a polícia havia identificado como alteradoras da ordem. Com efeito, o Chefe de Polícia destacou que deviam fortalecer o controle do "curandeirismo, da embriaguez e das gangues de jovens", para o que faziam um apelo à população para que contribuísse para acionar a polícia através da denúncia de delitos (La Gaceta, Tucumán, 27 de dezembro de 1953, p. 4).

Como foi assinalado, as representações que vislumbravam o desenvolvimento de uma crescente "corrupção moral" na sociedade provincial, e que foram características do mundo católico nos anos finais do governo peronista, faziam referência a outro sentido muito distinto daquele a que aludia a polícia. As palavras do representante máximo da Igreja local ilustraram isso de forma acabada. No marco em que se aprofundaram as reclamações pelos acontecimentos de agosto, o flamante bispo diocesano, Juan Carlos Aramburu, não se manteve alheio. Sua primeira carta pastoral ecoou as preocupações desencadeadas nessa conjuntura e 
enfatizou a necessidade de uma maior instrução doutrinária da população católica. Aramburu conclamou o laicato a defender o "sentido da moral católica", solicitação na qual subjaziam representações em torno da decência atravessadas por uma forte marca de classe. 0 flamante bispo associou a corrupção moral dos "novos tempos" à "pouca moderação nos costumes" e à "febre de diversões" que levavam ao "esquecimento" dos deveres cristãos (Boletín Oficial de la Diócesis de Tucumán, 19 de novembre de 1953, p. 10). Concomitantemente, dirigiu advertências à nova direção política para que não permanecesse "impassível" e defendesse "os princípios da moral cristã e cidadã". Nesse tom interpelou o intendente municipal, Eng. Roberto Delgado, solicitando a censura de "espetáculos decididamente imorais e lesivos à dignidade humana" cuja propaganda era tolerada pelas autoridades civis. ${ }^{13}$

Enquanto o bispo firmava a posição da Igreja, seu discurso revelava um deslocamento em relação ao sentido da moralização e aos modos de projetá-la. Ao atribuir, em parte, alguma responsabilidade à abstenção das autoridades políticas, Aramburu abria a porta que converteria a questão moral numa impugnação política, passo que habilitou a ACT a reorientar seu discurso contra o governo. Se analisamos o plano de ação desenhado pela direção laica a partir de 1953, articulado em tormo do "problema moral", surge com clareza como, diferentemente dos anos anteriores, as estratégias não tenderam à articulação com as agências estatais, mas sim foram levadas a cabo por fora dessas instâncias.

A poucos meses da posse de Luis Cruz como governador a ACT organizou uma campanha de defesa da moral pública. A campanha foi feita na Biblioteca Alberdi em outubro de 1952 e consistiu no pronunciamento de conferências sobre a "imoralidade reinante" devido à influência do cinema nos costumes e nas modas. Os oradores insistiram na necessidade de "pedir às autoridades municipais e policiais" que não tolerassem os que "rebaixam a moral pública" (La Gaceta, Tucumán, 24 de outubro de 1952, p. 5). As conferências foram o pontapé inicial para a organização da Liga da Decência, cujo objetivo seria exercer pressão sobre as instâncias governamentais para fazer prevalecer uma "moral essencialmente católica".

Não obstante, a Liga foi organizada apenas em 1954 junto com outras iniciativas dirigidas para reatualizar a moralização da sociedade. Essa demora na sua colocação em marcha deve ser atribuída aos acontecimentos de 1953 descritos anteriormente, que aceleraram a organização de atividades nessa direção e intensificaram a percepção generalizada de que a responsabilidade por tais acontecimentos residia na inoperância governamental. Por exemplo, foi a partir desse momento que a JD se propôs reorganizar o Secretariado de Moralidade encomendando aos jovens católicos (AJAC) a tarefa de dirigir sua recuperação. ${ }^{14}$

Concomitantemente, desde 1953 os membros da JD da ACT perceberam a diminuição da influência que outrora haviam exercido nas instâncias governamentais com respeito à 
instalação e ao controle da moralidade pública. Nesse sentido é representativo o percurso da Comissão de Moralidade da Prefeitura da Capital, em que membros da ACT tinham logrado exercer uma considerável influência durante os primeiros anos do governo peronista. No final de 1953, após a posse de um novo intendente (Juan Carlos Meuli), a Comissão de Moralidade e Cultura foi reorganizada e suas funções foram reformuladas sob a órbita dos "postulados principais da Doutrina Peronista". ${ }^{15}$ Ou seja, às funções de polícia moral - centradas no controle dos "bons costumes" e na censura dos espetáculos públicos - agregava-se a defesa da ordem social "concorde com a Doctrina Peronista". Desse modo, a comissão ampliava seus objetivos no sentido de "proibir a circulação de panfletos ou escritos de diversas características que traduzam ou representem por seu conteúdo uma incitação malsã ou contrária aos bons costumes da população ou aos sentimentos da argentinidade" (La Gaceta, Tucumán, 17 de abril de 1954, p. 4).

Com a reformulação de suas funções, a Comissão de Moralidade ampliou as perspectivas com relação aos tipos de expressões que deviam ser controladas e, eventualmente, censuradas. Mas a diferença principal residiu no fato de que a comissão tendia a se partidarizar, tomando cada vez mais distância dos critérios derivados da observância dos princípios católicos. Como era de esperar, a menor influência da marca católica nas atividades da Comissão de Moralidade expôs aos membros da JD a alternativa sobre a "conveniência" de manter sua representação. Da sua perspectiva, a mudança de perfil da comissão abria a possibilidade de que esta não fosse suficientemente rigorosa frente aos temas que preocupavam a direção laica tais como a moda indecente, os espetáculos imorais e a difusão da consciência em torno dos "maus filmes". ${ }^{16}$ Evidentemente, as modificações introduzidas na Comissão de Moralidade da Prefeitura geraram descontentamento entre um setor do laicato que percebeu que tais mudanças se fariam em detrimento da imposição de uma moral pública católica. 0 percurso posterior da comissão desmentiu sem dúvida esses temores, já que ela seguiu intervindo em sintonia com as exigências morais dos setores católicos (La Gaceta, Tucumán, 27 de novembro de 1954, p. 5).

\section{Os LIMITES DA "REATIVAÇÃO": A ACT NOS ÚlTIMOS ANOS PERONISTAS}

reativação do apostolado laico provincial em torno dos imperativos morais obedeceu,
entre outros, a um processo mais amplo, próprio do impulso que cobrou a militância católica em nível nacional. Com efeito, os estudos sobre o tema destacaram o processo de reorganização por que passou a associação católica desde que em 1952 o Episcopado argen- 
tino, em consonância com diretrizes emanadas de Roma, promoveu a recuperação do ativismo militante de anos anteriores (Acha, 2007). Fundamentalmente, os esforços se centraram na difusão do "apostolado ambiental", um modelo que aspirava a organizar os católicos "em seu lugar de trabalho" em vez de concentrar suas atividades nos limites da paróquia. Desse modo, a ACA rompia com a clássica organização de seus ramos por divisão de sexo e idade.

Em 1952 a ACA criou o ramo de Profissionais e Estudantes Católicos (APAC), com 0 qual procurou enquadrar aqueles atores numa nova organização e hierarquizar sua presença nas filas laicas, como parte de uma ofensiva católica tendente a estender sua influência social. O novo ímpeto militante comportou, especialmente na cidade de Córdoba e na Capital Federal, um tom desafiador ao governo ao se chocar com os planos deste último de organizar os mesmos setores com uma marca peronista. Com efeito, a partir do governo se projetaram novas entidades corporativas mediante a criação da Confederação Geral Econômica, destinada associar os setores empresariais, e as Confederações de Profissionais, Universitários e Estudantes Secundários.

Paralelamente a essa estratégia, orientada principalmente para os setores médios, 0 discurso do laicato militante pôs cada vez mais o acento na crítica dos costumes sexuais, na família e na moralidade, um terreno que resultou sensível ao governo. Ou seja, paulatinamente a ACA se erigiu cada vez mais como um espaço de oposição ao governo peronista, cujo discurso permitiu agrupar setores que até então não tinham sido capazes de oferecer uma "retórica alternativa à hegemonia peronista" (Acha, 2007, p.16).

Sem dúvida, o que nos interessa destacar aqui é que essa ofensiva católica no espaço público não teve o mesmo alcance em todas as dioceses. Nesse sentido, a partir da análise da ACT nos últimos anos peronistas é possível introduzir alguns matizes com respeito ao grau de reativação do apostolado laico, às dimensões que o movimento adquiriu e aos alcances que teve.

Como foi analisado, desde a década de 1950 também se observou na província de Tucumán uma reativação da militância laica fundamentalmente em torno da "defesa da moral católica". Sem dúvida, o processo pelo qual a ACA reformulou seus métodos de apostolado através do impulso à militância no local de trabalho e da organização da vertente de profissionais e estudantes, não teve seu correlato na diocese de Tucumán. Nesse sentido, os sinais de uma ofensiva católica não refletiram a contundência observada em outros espaços diocesanos, como por exemplo a cidade de Córdoba, convertida nesse sentido num foco gestor de iniciativas.

Diante das diretrizes da Junta Central da ACA em relação à necessidade de incorporar os métodos do apostolado ambiental e promover a criação de associações profissionais, a JD 
local realizou diferentes esforços que resultaram infrutíferos e levaram a não se poder concretizar nenhuma das duas propostas. As dificuldades nesse sentido geraram grandes debates na JD a respeito de como adaptar-se e dar respostas aos requerimentos das autoridades nacionais. $^{17}$

As atas de reunião da JD refletiram as vacilações da direção laica e as incertezas que predominaram com respeito ao rumo que tomaram os acontecimentos desde 1954. Uma conjuntura representativa das limitações que a associação experimentou foi o desconcerto de seus membros frente à criação da União de Estudantes Secundários (UES) na província. A nova instituição, impulsionada sob a gestão de Armando Mendez San Martín no Ministério da Educação, foi destinada a enquadrar as atividades dos estudantes fora dos horários de aula e, desse modo, ampliar as bases do movimento peronista (Caimari, 1995: 282). Seu surgimento gerou grande agitação e provocou a intensificação das críticas da oposição, que nela viu uma expressão da decadência moral em que havia ingressado o governo peronista, ao levar o presidente viúvo a mostrar-se publicamente rodeado de senhoritas.

Em agosto de 1954 chegaram delegados da UES metropolitana com o objetivo de organizar a associação em Tucumán (La Gaceta, Tucumán, 14 de agosto de 1954, p. 4). Diante desse dado, os dirigentes da ACT, com base no papel que concebiam para si mesmos na sociedade como guardiães e defensores da moralidade pública, se sentiram no dever de intervir e tomar posição em relação à nova associação estudantil que, na sua perspectiva, havia organizado em Buenos Aires "atos incompatíveis com a moral" e tinha como finalidade o "doutrinamento político" ${ }^{18} 0$ tema foi tratado nas reuniões da JD, e foi convidado o representante dos estudantes secundários católicos, que explicou que a grande maioria havia-se afiliado à UES, inclusive os da AC. Estes últimos, segundo o jovem, se haviam convertido em delegados da nova associação peronista. 0 problema para os estudantes católicos residia no desconhecimento dos objetivos da UES e em não saber se lhes era permitido aderir. ${ }^{19} 0$ desconcerto dos membros da JD foi evidente na medida em que resolveram dirigir suas dúvidas às autoridades nacionais. Sem dúvida, diante da falta de diretrizes, a JD debateu se deveria promover uma organização estudantil católica paralela ou "entrar e cooptar" a UES. Finalmente, a segunda estratégia foi a que se impôs dado que não se contava com os "elementos" necessários para seguir o caminho aberto pelo laicato de Córdoba, onde a criação do Movimento Católico de Juventudes tentava pôr um "limite moral" aos jovens peronistas organizados na UES, confrontando-se assim com os projetos do governo (Tcach, 1991; Capellupo, 2005).

Contrariamente, a ACT, dadas as suas limitações para desafiar o poder das organizações peronistas em Tucumán e suas diferenças com a AC de Córdoba, seguiu um caminho divergente. Nesse sentido, em contraste com outras dioceses, a Igreja de Tucumán não teve 
uma política definida para a juventude nem delineou estratégias alternativas para organizar esse setor da sociedade. A diluição da figura do bispo frente às iniciativas do laicato e a ausência de uma condução decidida não foram assim alheias à debilidade que a associação laica apresentou na província. Ou seja, Aramburu mostrou um estilo independente frente aos novos impulsos que os leigos buscaram outorgar à sua militância e se não os repreendeu, tampouco os estimulou nem lhes ofereceu um apoio institucional.

\section{CONSIDERAÇÕES FINAIS}

$\mathrm{O}$ objetivo do trabalho foi analisar a ACT como um ator que disputou a moral pública num contexto caracterizado pelas transformações sociais e culturais que o peronismo introduziu. As queixas pelas manifestações de "indecência" e "vícios" no principal passeio público da cidade, a impugnação da publicação de revistas e jornais "impudicos", a denúncia de falta de decoro dos espetáculos públicos, ou o que nas palavras do bispo podia significar uma "febre de diversões", revelaram que a reação moral do laicato militante se baseava, em parte, na rejeição dos novos padrões de sociabilidade e comportamentos públicos que se expandiram com o calor da irrupção peronista. A partir do imperativo de moralização social, articulado em torno de uma ideia da decência, do decoro e da moderação social, a ACT buscou vincular-se às agências estatais, em especial a Comissão de Moralidade da Prefeitura da Capital, interpelando as autoridades políticas e policiais. Num primeiro momento, a direção da ACT identificou no governo local um potencial aliado para realizar sua ação moralizadora. As respostas favoráveis às suas demandas e os espaços cedidos para desdobrar suas atividades impregnaram de otimismo as fileiras do laicato e ativaram sua militância. Desse modo, a ACT ganhou visibilidade pública e disputou o papel de guardiã da moral pública.

Sem dúvida, nessa disputa circularam diferentes sentidos da moralização. As agências estatais, como a polícia, ao mesmo tempo que respondiam parcialmente aos clanores católicos, exibiam um conceito de moral pública que, em seus fundamentos, diferia do buscado pela associação laica. Nesse sentido, a moral aparecia vinculada à ordem social e pública, donde os atores que a alteravam eram os que a polícia havia tradicionalmente perseguido: curandeiras, operários e pobres alcoolizados, pessoas envolvidas com a prática de jogos de azar proibidos etc. Na sua disputa pela moral pública, a ACT pareceu desafiar o poder tradicional da polícia enquanto instituição encarregada de resguardar essa ordem.

O imperativo de moralização que levou o laicato católico a buscar uma articulação com as agências estatais, e a nelas identificar um espaço receptivo para suas demandas, sofreu uma série de reformulações que o levaram a se converter, a partir de 1953, em fonte de 
disputas e de distanciamento do governo. Os acontecimentos confusos de agosto de 1953, que aludiam a episódios sensíveis à sociedade como a violência exercida sobre crianças, se converteram num cenário no qual se cristalizaram os diferentes sentidos da moralização. Nesse marco, o discurso articulado em torno da degradação ética da sociedade potencializou as atividades do laicato, sem dúvida, e as estratégias adotadas sofreram sensíveis mudanças. Se antes a pressão de suas ações estava voltada para influir nas condutas da população, para o que a articulação com as agências estatais era uma prioridade, no novo plano de ação desenhado pela direção laica as autoridades governamentais foram responsabilizadas pela "decadência moral". Esse processo coincidiu com a reação de setores médios e altos urbanos que caracterizou os últimos anos peronistas, carregada de uma forte marca de classe e exacerbada frente ao fortalecimento da percepção que aludia à degeneração dos costumes. Simultaneamente, esse discurso moral foi brandido pelo radicalismo, principal partido de oposição que, ao convertê-lo em uma impugnação política contra o governo, buscava encontrar uma oportunidade de interpelar o eleitorado católico.

0 discurso moralizador teve um alto impacto na sociedade, graças a uma ampla repercussão na imprensa periódica, e se converteu num substrato compartilhado com os setores políticos de oposição. Não obstante, essa reativação da militância laica, que em outros espaços diocesanos se viu refletida numa ofensiva católica, não gerou as mesmas consequências na diocese local. Ou seja, as tentativas de reavivar o ímpeto dos anos 1930 e as propostas de reativação institucional em torno do apostolado no local de trabalho e das organizações de jovens e profissionais não resultaram numa renovação das estruturas organizacionais da ACT, que teve de enfrentar limitações e obstáculos maiores que seus pares de outras províncias.

Em parte, a debilidade das estruturas da ACT se deveu ao fato de que as políticas de reativação do movimento laico provenientes do Vaticano - e do Episcopado nacional - não encontraram apoio institucional na diocese de Tucumán, liderada por um novo bispo que não as reproduziu nem incentivou sua adoção entre o laicato local. Tal direção diocesana outorgou amplos espaços de manobra às fileiras do laicato, lançadas à política através de um discurso moral e de decência, que encontrou um substrato comum com as críticas emanadas dos setores da oposição. Sem dúvida, quando esses discurso ganhou força, a abstenção do novo bispo ajudou, por outro lado, a desativar a ACT, cujas estruturas se viram debilitadas dada a falta de impulso institucional às políticas de reativação do movimento laico emitidas pelos órgãos superiores. Essa foi uma das diferenças que separaram os laicos de Tucumán de seus pares cordobeses e metropolitanos, especialmente dos primeiros, que a partir de 1954 se lançaram em direção a uma "ofensiva católica" que disputou espaços sociais com as organizações peronistas. Finalmente, quando em setembro de 1955 irrompeu a insurreição cívico-militar contra 
o governo de Perón, a sociedade de Tucumán se manteve expectante frente aos acontecimentos desencadeados na cidade de Córdoba, epicentro do Golpe de Estado que teve entre seus principais protagonistas setores do laicato católico e a hierarquia eclesiástica dessa província.

\section{NotAS}

1 A maior parte dos estudos sobre a ACA se concentrou no período de surgimento e desenvolvimento da organização (1931-1943). As pesquisas destacaram o surpreendente crescimento da associação desde a sua fundação, aspecto que as levou a analisar sua estrutura, funcionamento, tendência ideológica e influência na dinâmica política (Mallimaci, 1991; Zanatta, 1996; Bianchi, 2002). Nos últimos anos, novos estudos avançaram nesses aspectos (Blanco, 2008; Ghio, 2007).

2 Os estudos de César Tcach e Jane Walter, centrados em Córdoba, reconstituíram o processo pelo qual essa província se converteu no epicentro de uma "ofensiva católica" - liderada pela Ação Católica, por um setor do clero e avalizada pela hierarquia - em resposta aos desafios que o peronismo propunha (Tcach, 1991; Walter, 2002: 265-309).

3 Criada sob o Papado de Pio XI, a Ação Católica (AC) nasceu na Itália em 1923 e teve uma ampla difusão na América Latina a partir do final da década. Foi concebida com o objetivo de reunir os militantes católicos sob a autoridade episcopal. Seu objetivo primordial foi a "recristianização dos costumes e da vida pública", e assim se converteu numa ferramenta fundamental na tarefa de "instaurar o reino de Cristo na sociedade" (De Roux, 2014).

4 Desde o final do século XIX a indústria açucareira constituiu a principal atividade econômica da província e, a partir de então, gravitou em sua configuração social, política, cultural e religiosa (Campi y Bravo, 2010). Antes da fundação do FOTIA, sindicato formado no calor das novas políticas sociais impulsionadas por Perón a partir da Secretaria do Trabalho e Previdência, os trabalhadores do açúcar tinham feito algumas tentativas incipientes de organização, ainda que de modo geral estas tenham resultado efêmeras e não tenham conseguido exercer uma influência considerável.

5 Archivo de Acción Católica Tucumana (caqui em diante AACT), Carpeta Asambleas Diocesanas, "Memoria del período 1944-1947".

6 AACT, Acta de reunión de Junta Diocesana (JD), Tomo III (1948-1954), 12/7/1950.

7 AACT, Acta de reunión de JD, Tomo III (1948-1954), 18/5/1949.

8 AACT, Acta de reunión de JD, Tomo III (1948-1954), 20/12/1950.

9 AACT, Acta de reunión de JD, Tomo III (1948-1954), 20/12/1950 e 23/08/1950.

10 AACT, Acta de reunión de JD, Tomo III (1948-1954), 12/12/1951.

11 No mês de junho de 1953 a imprensa divulgou a notícia da morte de Julio Víctor Aráoz, dirigente peronista que apareceu sem vida num comissariado da capital. Os rumores que responsabilizavam o filho do governador, que numa briga e sob os efeitos do álcool teria assassinado Aráoz, se espalharam rapidamente e originaram críticas dos partidos de oposição. Esse incidente seria investigado posteriormente pela Comissão Nacional de Investigações criada em outubro de 1955 pelo presidente interino E. Lonardi. Archivo General de la Nación (AGN), Archivo Intermedio, Fondo Comisión Nacional de Investigaciones, Caja 1086. 
12 AACT, Acta de reunión de JD, Tomo III (1948-1954), 19/8/1953.

13 AAT, Correspondencia con autoridades municipales, Carta de Juan Carlos Aramburu al Intendente Municipal, Ing. Roberto Delgado, 8/7/1952.

14 AACT, Acta de reunión de JD, Tomo III (1948-1954), 4/2/1954.

15 Em 1952 o Congresso Nacional converteu a Doutrina Peronista em Doutrina Nacional, definindo-a como fundamento da educação e da cultura argentina. Trata-se de uma política que fez parte de um processo mais amplo, que obedeceu a uma nova etapa do movimento de ordenamento e afirmação nas esferas de governo, como também de extensão da sua presença social. Sobre a mudança de direção estratégica do governo peronista, ver Cattaruzza (2009: 216-223).

16 AACT, Acta de reunión de JD, Tomo III (1948-1954), 4/2/1954.

17 AACT, Acta de reunión de JD, Tomo III (1948-1954), 16/6/1954.

18 AACT, Actas de reunión de JD, Tomo III (1948-1954), 5/8/1954.

19 AACT, Actas de reunión de JD, Tomo III (1948-1954), 5/8/1954.

\section{REFERÊNCIAS BIBLIOGRÁFICAS}

ACHA, Omar. El laicado católico pasa a la acción (Argentina, 1952-1955). In: Jornadas Interescuelas/ Departamentos de Historia, $\mathrm{XI}^{\circ}$, 2007, Argentina (Tucumán).

——.Tendencias de la afiliación en la Acción Católica Argentina. Travesía, Tucumán, n. 12, 2010, p. 7-42.

_. Los muchachos peronistas. Orígenes olvidados de la Juventud Peronista (1945-1955). Buenos Aires: Planeta, 2011.

- Crónica sentimental de la Argentina peronista. Sexo, inconsciente e ideología, 1945-1955. Buenos Aires: Prometeo, 2013.

ADAMOVSKY, Ezequiel. Historia de la clase media argentina. Apogeo y decadencia de una ilusión, 1919-2003. Buenos Aires: Planeta, 2009.

BIANCHI, Susana. Catolicismo y peronismo: religión y política en la Argentina 1943-1955. Tandil: IEHS, 2001.

. La conformación de la Iglesia católica como actor político-social. Los laicos en la institución eclesiástica: las organizaciones de elite 1930-1950. Anuario IEHS, Tandil, n. 17, 2002.

BLANCO, Jessica. Modernidad conservadora y cultura política: la Acción Católica Argentina 1931-1941. Córdoba: Facultad de Filosofía y Humanidades, Universidad Nacional de Córdoba, 2008.

CAIMARI, Lila. Perón y la Iglesia católica. Religión, Estado y sociedad en la Argentina 1943-1955. Buenos Aires: Ariel, 1995.

CAMPI, Daniel y BRAVO, M. Celia. Aproximación a la historia de Tucumán en el siglo XX. Una propuesta de interpretación. In: ORQUERA, Fabiola (coord.). Ese ardiente Jardín de la República. Formación y desarticulación de un campo cultural: Tucumán 1880-1975. Córdoba: Alción Editora, 2010.

CAPELLUPO, Rafael. 1955. "Revolución" en Córdoba. Crónica de una cruzada cívico-militar polémica. Córdoba: Emporio, 2005. 
CATTARUZZA, Alejandro. Historia de la Argentina, 1916-1955. Buenos Aires: Siglo XXI, 2009.

DE ROUX, Rodolfo R. La romanización de la Iglesia católica en América Latina: una estrategia de larga duración. Pro-Posições, Campinas, v. 25, n. 1 (73), 2014.

DI STEFANO, Roberto y ZANATTA, Loris. Historia de la Iglesia argentina. Desde la conquista hasta fines del siglo XX. Buenos Aires: Mondadori, 2000.

GHIO, José María. La iglesia católica en la política argentina. Buenos Aires: Prometeo, 2007.

JAMES, Daniel. Resistencia e integración. El peronismo y la clase trabajadora argentina 1946-1976. Buenos Aires: Sudamericana, 1999.

MALLIMACI, Fortunato. Movimientos laicales y sociedad en el período de entreguerras. La experiencia de la acción católica en la Argentina. Cristianismo y Sociedad, México, n. 108, 1991.

RUBINSTEIN, Gustavo. Los sindicatos azucareros en los orígenes del peronismo tucumano. San Miguel de Tucumán: Universidad Nacional de Tucumán, 2006.

SANTOS LEPERA, Lucía. La Iglesia católica y su relación con el gobierno peronista, 1943-1955. In: GUTIÉRREZ, Florencia y RUBINSTEIN, Gustavo. El primer peronismo en Tucumán. Avances y nuevas perspectivas. Tucumán: Editorial de la Universidad Nacional de Tucumán, 2012, p. 171-216.

y LICHTMAJER, Leandro. 2013. Transitando rumbos paralelos. Radicales y católicos durante el primer peronismo en Tucumán. Prohistoria, Rosario, n. 19, p. 123-143.

TCACH, César. Sabattinismo y peronismo. Partidos politicos en Córdoba 1943-1955. Buenos Aires: Sudamericana, 1991.

WALTER, Jane. Catolicismo, cultura y lealtad política: Córdoba, 1943-1955. In: VIDAL, Gardenia y VAGLIENTE, Pablo (comp.). Por la señal de la cruz: Estudios sobre la Iglesia Católica y Sociedad en Córdoba s. XVII-XX. Córdoba: AR, Ferreyra, 2002, p.265-309.

ZANATTA Loris. Del Estado liberal a la Nación católica. Iglesia y Ejército en los orígenes del peronismo. 19301943. Buenos Aires: Universidad Nacional de Quilmes, 1996. 